\title{
Leopoldo M. Bernucci - Paraíso suspeito: a voragem amazônica
} São Paulo: Edusp, 2017

\author{
Gabriel Cabrera Becerra
}

La vorágine, de José Eustasio Rivera (1888-1928), es un hito de la literatura colombiana publicado en 1924, y forma parte de un conjunto de obras en el contexto latinoamericano que se ocupan de la explotación del caucho y, en especial, de los abusos o prácticas criminales que se dieron durante la extracción de este recurso natural. Ha habido una continuidad de este tema literario en otras obras como A selva (1930), de José María Ferreira de Castro; Toa (1934), de César Uribe Piedrahita; Canaima (1935) de Rómulo Gallegos; El mundo es ancho y ajeno (1941) de Ciro Alegría; y la reciente narración El sueño del celta (2010), del nobel de literatura Mario Vargas Llosa.

La publicación de Leopoldo M. Bernucci se da treinta años después del esfuerzo editorial que la investigadora Monserrat Ordoñez hiciera en Colombia con la compilación La vorágine: textos críticos, trabajo que en su momento reunió una serie de escritos sobre la acogida, reconocimiento, vigencia y escritura de esta novela, como también del trabajo más reciente de Carlos Páramo, El camino hacia La vorágine: dos antropólogos tempranos y su incidencia en la obra de José Eustasio Rivera, en el que explora con amplitud la conexión de La vorágine con los textos del venezolano Samuel Darío Maldonado e insinúa lo propio con la obra Infierno verde del brasileño Alberto Rangel. A lo largo de cinco capítulos, Bernucci renueva los enfoques y valoraciones sobre esta última obra y explora en profundidad la relación entre la novela colombiana y varias obras literarias brasileñas.

Bernucci se desempeña como profesor de Estudios Latinoamericanos en el departamento de Español y Portugués de la Universidad de California Davis. Obtuvo su grado doctoral con especialidad en lengua española y literatura latinoamericana en la Universidad de Michigan (Ann Arbor) y ha sido docente en las universidades de Yale, Colorado-Boulder, São Paulo y Texas (Austin).

El libro Paraíso suspeito hace un detallado examen del lugar e importancia de la novela, cuyos contenidos denuncian la violencia de los caucheros contra los indígenas, pero que en verdad es posterior a las denuncias que como funcionario público su autor ofreciera años antes en informes relacionados con sus ocupaciones como funcionario del Ministerio de Relaciones Exteriores. La obra, que cuenta con traducciones a más de quince idiomas, aún se sigue editando e incluso inspira formatos renovados, como la obra homónima de Óscar Pantoja y José Luis Jiménez, la primera adaptación a novela gráfica de una novela colombiana, que además fue producida recientemente en blanco y negro.

Es innegable que la experiencia de vida de su autor en sus viajes, lecturas y conversaciones fueron los insumos de su narrativa que, como nos recuerda Leopoldo Bernucci, contó con un nutrido y variado grupo de lectores que alabaron o desaprobaron su contenido. De la bibliografía citada por Bernucci se puede colegir que, en español, la obra ha tenido al menos seis ediciones. Sin embargo, como se trata de un ejercicio comparativo con Brasil y se sabe que fue traducida al portugués, sería bueno conocer cuántas ediciones ha tenido la obra, información que no suministra el autor.

Especialmente significativa es la ruta investigativa que emprende Bernucci y que revela que, si bien hay información sobre el viaje de Rivera a la Amazonía entre 1922 y 1923, poco se había estudiado en detalle la influencia que dicha experiencia tuvo sobre él y su obra. Rivera recorrió los ríos Orinoco y Negro y pasó por São Gabriel da Cachoeira, Santa Isabel y Manaos. Es justo en este último lugar donde obtuvo, por compra o regalo, obras literarias con las que su novela tiene evidentes similitudes. Una de ellas es Os sertões (1902), de Euclides da Cunha (1866-1909), que contiene numerosos apartes que se traslapan con otros en la obra de Rivera. Ambos autores tuvieron vidas sorprendentemente paralelas: fueron funcionarios públicos en los Ministerios de

\footnotetext{
* Doctor en Historia y profesor de la Universidad Nacional de Colombia, Medellín, Colombia. E-mail: gcabrerabe@unal.edu.co
} 
Relaciones Exteriores de sus respectivos países y participaron de sendas expediciones relacionadas con temas fronterizos, E. da Cunha en 1905 y J. E. Rivera en 1922-1923. Juntos permanecieron cerca de un año en la región amazónica, padecieron la malaria, tuvieron inconvenientes en sus viajes y compartieron la valoración de su respectiva realidad nacional como un elemento nodal de su vida, que en ambos casos fue corta (Bernucci, 2017, p. 55-60).

Pero no fue sólo Os sertões la obra que influenció a Rivera. Euclides hizo el prefacio de Infierno verde (1908), de Alberto Rangel, obra que le fue obsequiada a Rivera en São Gabriel da Cachoeira por el Obispo salesiano Pedro Massa (1880-1968) en 1922 (Bernucci, 2017, p. 82). Otra obra que sin duda también conoció Rivera fue Os seringaes: pequenas notas (1914), de Mário Guedes, sobre la que Bernucci señala que "constituye una fuente infinita de datos sobre los medios de extracción del caucho y la industria de ese producto en la Amazonía" (Bernucci, 2017, p. 85). Algunos libros brasileños fueron comprados por Rivera en Manaos y Belém do Pará. La prueba fotográfica de ello se incluye como anexo en un libro de otro investigador, que señala cómo al menos una veintena de libros que hacen parte de la biblioteca personal de Rivera - ubicada hoy en la facultad de teología y filosofía de la universidad javeriana en Bogotá - tiene anotacione, fragmentos subrayados y la firma datada de Rivera. Un ejemplar de Os seringaes firmado el día 19 de agosto de 1923 dice: “Ley y anote este libro en altamar a bordo del Camoens en viaje de Belém do Pará hacia la isla de Trinidad" (Cárdenas, 2014, p. 83).

Bernucci asegura que otros elementos de la obra, como los contenidos etnográficos que revelan prácticas indígenas, el empleo de los nombres de flora y fauna amazónica o la violencia ejercida contra los indígenas, permiten constatar que las lecturas de Rivera fueron muchas más. Este tipo de informaciones están, por ejemplo, en textos de viajeros y exploradores que transitaron parte del Brasil o de Colombia, como Alfred Russell Wallace, Johann Spix y Carl von Martius, Theodor Koch-Grümberg, Robert Avé-Lallemant, Walter Hardenburg, Thomas Whiffen y Eugene Robuchon, entre otros.

Así mismo es claro que, además de otros textos, el trato personal con Demetrio Salamanca (1853-1925) le dio múltiples informaciones al autor de La vorágine (Cabrera, 2007, p. 61). Salamanca fue un ingeniero colombiano naturalizado brasileño, cónsul ad honorem del Brasil entre 1896 y 1900 con sede en Bogotá y cónsul general de Colombia en Manaos entre 1921 y 1925, los años en que Rivera visitó la región y escribió La Amazonía colombiana (1916). Además, José Eustasio Rivera con certeza leyó las obras Las crueldades de los peruanos en el Putumayo (1911), de Vicente Olarte Camacho y el Memorandum de viaje (1905), de Joaquín Rocha.

La exuberancia de la selva es otro elemento que se destaca en La vorágine, y Bernucci destaca el paralelismo entre la novela y textos brasileños en los que también hay una identificación bilingüe (en español y portugués) de plantas, mamíferos, aves, reptiles e insectos. Además de la riqueza y diversidad de la Amazonía, su valoración como un ambiente hostil también se expresa en el hambre, la desorientación, el delirio y la locura de quienes están allí. Este rasgo, según afirma Bernucci, se nutre de obras como El corazón de las tinieblas, de Josep Conrad, o Por el sur de Colombia, de Miguel Triana, así como de muchos relatos más de viajes que Rivera sin duda leyó y que le permiten construir su propósito central: mostrar "el poder de la naturaleza sobre el civilizado" (Bernucci, 2017, p. 218).

Las evidencias de la violencia y trabajos del caucho no son solamente textuales, aspecto de lo que se ocupa el tercer capítulo del libro. Bernucci amplía la discusión sobre las imágenes que acompañaron las cuatro primeras ediciones de La vorágine y que en la quinta edición fueron sustituidas por cuatro mapas que muestran la ruta de Barrera, Silva y Cova, tres caucheros que aparecen en la obra. En realidad, la ruta real no corresponde al itinerario, por lo que se puede concluir que el propósito de incluirla era causar un efecto de verosimilitud en el texto. Hay aquí una similitud más que Bernucci desarrolla con relación a la obra de Euclides da Cunha, pues Os sertões contiene tres imágenes de la guerra de los Canudos con el propósito de afianzar la veracidad del relato.

Lo llamativo de dos de las imágenes que Rivera incluyó en su obra, Un cauchero y El cauchero Clemente Silva, es que son una reproducción de dos imágenes tomadas en Brasil por el fotógrafo de origen alemán George Huebner (1862-1935). En 1899, Huebner abrió su propio estudio 
fotográfico en Manaos, la Fotografía alemana, que pronto se convirtió en el mejor local del ramo en la Amazonía (Cabrera, 2018, p. 58). Rivera probablemente tomó estas imágenes postales en un formato distinto, quizá la reproducción en la revista Kosmos, de 1904, publicada en Manaos (Bernucci, 2017, p. 257). En realidad, las imágenes tenían el propósito de dar veracidad a la narración pero lo paradójico era que las dos eran de caucheros del Brasil.

Durante mucho tiempo, las interpretaciones de la novela asociaron al personaje de Arturo Cova con el autor José Eustasio Rivera, aunque lo que haya en ella son múltiples narradores, como lo revela otra investigadora (Benso, 1975). La inclusión de una tercera fotografía, cuyo pie de foto indica que se trata de Arturo Cova en una barraca en Guaracu, pretendía afirmar la verdad de los hechos mencionados en la novela, pero la imagen se ubica en un lugar donde Rivera no estuvo. Hasta hoy persisten las suspicacias de que se trataba de Rivera y no de Cova, intentando suprimirlas es que Rivera retiro la fotografía de la quinta edición de su novela. Ya sobre esta imagen se había indicado, como reitera Bernucci recordando el trabajo de Páramo, que no es posible afirmar que quien aparece sea José Eustasio Rivera, pues la calidad de la foto es muy deficiente, e incluso podría tratarse de una imagen retocada. Como concluye Bernucci: "el novelista colombiano sin duda aumentó el grado de realismo del libro, eliminando la más evidente correferencialidad entre sí y Cova" (Bernucci, 2017, p. 254).

Finalmente, el texto se acompaña de unas notas biográficas sobre los personajes de tiempos de la cauchería que se presentan con el subtítulo (principais dramatis personae); la pregunta de si la novela La vorágine y sus personajes son tomados de la realidad o la ficción se sigue planteando. Pero dicha tensión no debería ser el punto nodal de su lectura. Como Carlos Páramo reveló en su trabajo en el informe diplomático del venezolano Samuel Darío Maldonado, escrito en 1906, es clara la existencia de Tomás Funes y Arturo Cova, dos seres reales en tiempos de la cauchería en la zona del Orinoco que Rivera visitó. El autor tuvo acceso este material y probablemente conoció o escuchó hablar de Arturo Cova (Páramo, 2006, p. 46).

La lectura de este libro es completamente placentera. Como investigador de antropología e historia de la Amazonía, siempre he intentado leer la realidad de la región a ambos lados de la frontera. Este libro emprende un camino original, pero desde la literatura, y se detiene en contenidos y fuentes en torno a la realidad compartida de la explotación cauchera, su violencia y los efectos sobre las poblaciones locales, efectos que no son ajenos a la literatura. El mérito de este libro es examinar minuciosamente las conexiones que existen entre un autor colombiano y varios autores emblemáticos brasileños. Las obras de Euclides da Cunha y Alberto Rangel muestran los vínculos, y se sugiere una conexión con otras obras que merecen ser estudiadas. Sobre esto cabe señalar que en otras regiones como el Perú existen los relatos por entregas de Carlos Germán Amézaga (1862-1906), publicados en la revista Prisma entre 1905 y 1906 y posteriormente en El Ateneo de Lima, en 1907, bajo el título de La leyenda del caucho. Este último texto fue resultado de su viaje a la Amazonía hecho hacia 1900. Estos contenidos permitirían extender los ejercicios comparativos y su análisis.

La lectura reciente de un trabajo inédito de Edwin Fernando Carrión realizado para obtener su título de Magíster en literatura y su valioso ejercicio de síntesis de los textos críticos que hasta entonces existen sobre la novela La vorágine son una confirmación de la originalidad del trabajo de Leopoldo Bernucci. A pesar de su cercanía geográfica, Brasil es un país lejano para la mayoría de los colombianos. No obstante, Bernucci logra conectar, a través de su propuesta, las letras de Colombia y Brasil. La vorágine se seguirá leyendo más allá de la pregunta sobre su realidad o ficción. Rivera no consideraba su obra una novela histórica y, en cambio, quería que fuera un texto de un alcance mayor. Su novela está "enraizada en la realidad, pero también refleja y modela esa realidad" (Bernucci, 2017, p. 232), una que los colombianos compartimos Brasil. 


\section{Referências}

BENSO, Silvia (1975). La vorágine: una novela de relatos. Thesaurus, Bogotá, v. 30, n. 2, p. 271-290.

BERNUCCI, Leopoldo M. (2017). Paraíso suspeito: a voragem amazônica. São Paulo: Edusp.

CABRERA, Gabriel (2018). Un siglo de fotografías del Alto río Negro, Vaupés, 1865-1965. Boletín de Antropología, Medellín, v. 33, n. 55, p. 151-190.

CABRERA, Gabriel (2007). Los diplomáticos colombianos y la nacionalización de la Amazonía. Memoria E Sociedad, Bogotá, v. 11, n. 22, p. 51-68.

CÁRDENAS, Freddy Orlando (2014). La vorágine de Euclydes da Cunha. Manaus: Editora da UFAM.

CARRIÓN, Edwin Fernando (2012). La vorágine de José Eustasio Rivera: expresión de la ineficacia estatal y sus efectos en la sociedad colombiana. Tesis (Maestría en Literatura) - Pontificia Universidad Javeriana, Bogotá.

ORDOÑEZ, Monserrat (1987). La vorágine: textos críticos. Bogotá: Alianza Editorial Colombiana.

PANTOJA, Óscar; JIMÉNEZ, José Luis (2017). La vorágine. Bogotá: Resplandor.

PÁRAMO, Carlos (2006). El camino hacia La vorágine: dos antropólogos tempranos y su incidencia en la obra de José Eustasio Rivera. Cuadernos de los seminarios: Ensayos de la Maestría en Antropología, Bogotá, n. 1 , p. 35-54. 